\title{
気候性地形療法を基本にした「クアオルト健康ウオーキング」と 日本クアオルト協議会，日本クアオルト研究機構の役割
}

\author{
小 関 信 行 \\ (日本クアオルト研究機構)
}

ドイツは統合医療で, 自然療法のクアオルト（療養地・ 健康保養地）では，治癒，緩和，予防に効果のある4つ の自然の治療要因（温泉・泥など土に由来するもの, き れいな空気や太陽光線などの気候, 海水・海風などの海, 水・運動・食慨・植物・秩序の 5 つの療法を柱としたク ナイプ式）で，医療保険が適用され，最高 3 週間滞在 して治療している。現在, 自己負担で保養に来る利用 者も 8 割以上と多くなり, 2015 年の統計では, 宿泊数 $117,872,581$ 泊, 滞在客数 $24,284,073$ 人, 平均 4.70 泊の利 用となっている. クアオルトは, 2007 年現在, 様々な厳 しい品質を具備して, 374 カ所が法律で認定されている.

「気候性地形療法」は, 山岳や海辺にある気候のクア オルトで処方される運動療法で, 1990年代後半から医療 保険が適用された，比較的新しい療法である。これは， 運動負荷が計測された野外の道や砂浜を歩く「地形療法」 に,「冷気と風」という気候の要素を活用し, 運動中, 皮 虚温を平均 2 度低下させること, これは主観的な温冷感 覚では「やや冷える」と感じる程度を維持し, 運動効果 を増すという手法である。適応症は，心臟リハビリや高 血圧，骨そしょう症となっている，治療では，現代医療 を習得した後に自然療法を学んだクアオルト専門医の診 察を受け，自転車エルゴメーターで体力測定をし，持久 力に合った 1 週間の処方を気候療法士という運動指導の 専門職に渡し，適切な運動負荷で治療を実施する。期間 は 3 週間, 週 3 4 回, 傾斜のある土地を治療負荷で歩 く20４0分の継続的運動負荷とともに, 緩和の手法であ るヨガの呼吸法や自律訓練, 水中運動なども処方されて いる. 1 週間ごと, 専門医の診察を受けて再処方されて いる. 運動負荷は, 上りの区間のみ $160-$ 年齢の心拍数 でコントロールし，血圧降下剤を服用する人は，心拍を 抑制する薬剤もあるため 10〜20\%減じた目標心拍数とし ている，血圧の治療の場合，治療が進むごとに，高血圧 や低血圧がともに，平均值に収束する状況となる．

日本では山形県上山市が，気候性地形療法を見出した ミュンヘン大学のアンゲラ・シュー教授の指導のもと, 2008年, ミュンヘン大学から日本で初めて気候性地形療 法コース (5 カ所 8 コース) の認定を得て, ドイッの気 候療法士を手本としたガイドを育成しながら，日本人向 けにアレンジした「クアオルト健康ウオーキング」とし て提供を開始した。年々利用者が増加し，現在は，年間 360 日毎日認定コースを変えて提供し, 健康づくりを推
進している。この参加者は, 平成 27 年度で 5700 人, 平 均 15.9 人で, 割合は，40代 $4 \% ， 50$ 代 $12 \% ， 60$ 代 $49 \%$, 70 代 $31 \%$, 男女比は, 男 $27.5 \%$, 女 $72.5 \%$, 市内 $53 \%$, 市外 $47 \%$ となっており，その他関連するウオーキングを 含めると, 年間 13,800 人が参加している.

現在，ドイツのクアオルトを手本とし，日本の社会に 適合する滞在型の健康保養地である日本型クアオルトを 目指した自治体が集まり，「日本クアオルト協議会」が, 2015年 1 月に設立された。現在，地域住民の健康づくり と交流人口の拡大を目指し, 秋田県三種町, 山形県上山 市, 群馬県みなか及町, 新潟県妙高市, 石川県珠洲市, 和歌山県田辺市, 島根県大田市, 大分県由布市の 8 つの 自治体で構成されている。しかしながら，各自治体の取 り組み内容に強弱があるため, 当協議会では, どの自治 体でも高い品質の日本型クアオルトを提供するため, 健 康, 医療, 環境, 景観, 観光・産業, 計画 - 連携という 6 つの領域に, 各々 10 項目, 合計 60 の指標を定め, 自己 評価した上で, 高い指標の自治体にノウハウを学び品質 向上に努めている.

しかし, 自治体は医科学の専門ではないため, 健康プ ログラムの設計やエビデンス調査など, ドイツと同様に 研究機関が学術的に支援する必要があった。そこで，日 本型クアオルトの育成に携わった研究者等を集めた「日 本クアオルト研究機構」が, 日本クアオルト協議会の設 立後，速やかに組織されている。また，日本型クアオル トやクアオルト健康ウオーキングの実務的な取り組みを 支援する必要があり，2016年日本クアオルト研究所が設 立された。

現在, 日本クアオルト協議会と日本クアオルト研究機 構が連携し, 日本クアオルト研究所が具体的な手法や人 材育成などの実務を支援しながら，自治体の公共政策と して住民の健康づくりを推進している.

クアオルト健康ウオーキングは, 協議会の中で, 秋田 県三種町, 山形県上山市, 石川県珠洲市, 大分県由布市 が実施するほか, 青森県青森市, 山形県天童市, 同県西 川町, 岐阜県白川村で実施し, 街のなかでは, 日本クア オルト研究機構の事務局が名古屋市の白川公園で, 気候 性地形療法の要素を活用した街なかウオーキングとして 定期的に実施している，今後ますます，国民の健康づく りに拈て，無理のないそして楽しく効果的なクアオル 卜健康ウオーキングが拡大すると考えられる。 